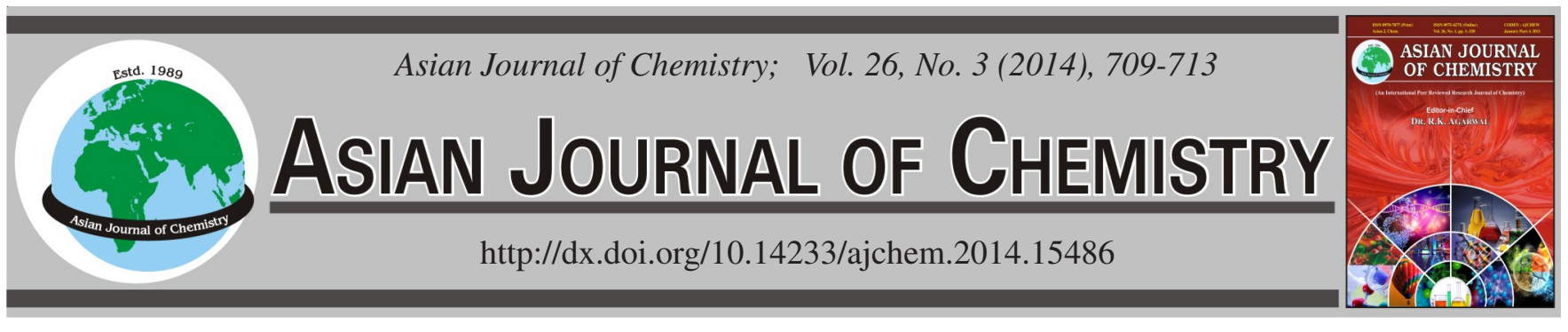

\title{
Effect of Different Influent Flow Distribution Ratios on Multistage A/O Process for Removal of Carbon and Nitrogen
}

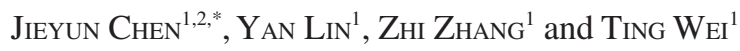

${ }^{1}$ Key Laboratory of Three Reservior Region's Eco-Enviroment, Ministry of Education, Chongqing University, Chongqing 400045, P.R. China ${ }^{2}$ Chongqing Jianlong Environmental Engineering Co., Ltd., Chongqing 401147, P.R. China

*Corresponding author: Tel: +86 23 65127191; E-mail: chenjieyun1004@126.com

\begin{abstract}
Three-stage step-feed A/O system was applied to treat sewage with low carbon source. The removal of organic matter, nitrification and denitrification removal efficiency under different influent flow rate distribution ratios were discussed. It was showed that different flow distribution ratios $(4: 3: 3 ; 5: 3: 2 ; 6: 3: 1)$ had a little effect on organic matter removal and nitrification efficiency, $\mathrm{COD} \mathrm{NH}_{3}-\mathrm{N}$ of effluent were below 30 and $1.0 \mathrm{mg} / \mathrm{L}$, respectively, by monitoring water quality along the reactor, but denitrification efficiency was considerably affected. When flow distribution ratio was 5:3:2, carbon source of sewage was effectively used and the system achieved the optimum efficiency of nitrification. When flow distribution ratio was 5:3:2, the effluent total nitrogen was $5.7 \mathrm{mg} / \mathrm{L}$ and removal ratio of total nitrogen was $82.9 \%$, which was better than the nitrogen removal efficiency under the flow distribution ratios of 6:3:1 and 4:3:3. In summary, the step-feed system is superior to single point feed system in the aspect of effectively usage of carbon sources and energy saving.
\end{abstract}

Keywords: Influent flow distribution ratios, Step-feed system, Biological nitrogen removal, Low carbon source.

\section{INTRODUCTION}

The influent was divided multiply into anoxic stage, respectively and aerated periodically ${ }^{1,2}$, in order to use the carbon source rationally. It formed the multistage step-feed A/O system. Step-feed influent not only supplied the denitrifying bacteria with adequate carbon source ${ }^{1}$, but also reduced the influence of front-stage effluent dissolved oxygen and $\mathrm{pH}$ on later anoxic stage $\mathrm{e}^{3-5}$. In addition, nitrifying bacteria belonged to chemoautotroph aerobic bacteria, requiring a relatively low organic carbon concentration. Organic carbon concentration should below $20 \mathrm{mg} / \mathrm{L}$ in general and a high BOD concentration would make the heterotrophic bacteria with higher proliferation rate be the dominate species in the system and the nitrifying bacteria would be in the inferior stage which was not conducive for nitrification ${ }^{6-8}$. Staged reactor and the step-feed influent mode made the organic matter in influent which passing through the anoxic stage could be degraded effectively and provide a good growing environment for nitrifying bacteria. For sewage with low $\mathrm{C} / \mathrm{N}$, carbon sources were the restrict factor for denitrifying and phosphorus releasing. Even though, making full use of carbon source of raw sewage could not meet the effluent emission standard of total nitrogen, total phosphorus. Multistage A/O system used the carbon sources in raw sewage as far as possible. It was especially applicable to treat municipal sewage with low $\mathrm{C} / \mathrm{N}$. Compared to the traditional biological process, with the same reactor volume and solid loading in secondary sedimentation tank, step- feed process treating volume could increase $100-140 \%$ and it would larger with the increase of the stages. But when the number of stage is beyond 5 , the performance advantages were no longer obvious ${ }^{9}$, nitrogen removal rate could only increase slightly by the stage number increasing when it was over 4 , so the number of stage is 2-4 in practical engineering. The analysis from the mathematical model of step-feed system found that three-stage step-feed process could get the best operation effect $^{10}$. In the continuous step-feed A/O system, there were many factors affecting the running efficiency and the removal efficiency of total nitrogen, for instance, dissolved oxygen concentration, return sludge ratio, volume ratio of anoxic and aerobic zone and flow distribution ratio. However, studying the mechanisms of the multistage $\mathrm{A} / \mathrm{O}$ process is in its infancy and the research stage stayed in simulation stage or simulation of sewage stage. Still, there were sewage treatment companies adjusting the original process and transforming the original process into multiple $\mathrm{A} / \mathrm{O}$ process and the system behaviour proved desirable. It also reflected the potential advantages of the multiple $\mathrm{A} / \mathrm{O}$ process ${ }^{11}$, but the theory of connection between operation adjustment and removal effect were lacking of directive function. 
The common $\mathrm{C} / \mathrm{N}$ of municipal sewage was around 6 and it was chosen as object of the study. The effect of different influence distribution ratios on three-stage step-feed $\mathrm{A} / \mathrm{O}$ system's removal efficiencies of nitrogen and carbon were discussed. It was in order to provide designing and performance parameter for practical wastewater plants and also provide theoretical basis for wastewater plants upgrading.

The experiments were carried out based on the single factor investigation, the main factor was influent distribution ratio $(4: 3: 3,5: 3: 2,6: 3: 1)$ and other factors remained the same, the $\mathrm{C} / \mathrm{N}$ maintained $c a$. 6 . In that case, the removal efficiency of organic matter, efficiencies of nitrification and denitrification and removal efficiency of total nitrogen and total phosphorus were discussed.

\section{EXPERIMENTAL}

The experimental devices and multistage $\mathrm{A} / \mathrm{O}$ reactor were shown in the Fig. 1. The external dimensions of the multistage A/O reactor (long $\times$ wide $\times$ high) were: $720 \mathrm{~mm} \times 660 \mathrm{~mm} \times$ $1000 \mathrm{~mm}$, the height included $30 \mathrm{~cm}$ for reserved capacity. The total effective volume was $330 \mathrm{~L}$. The transverse direction was divided into 3 parts to form the three-stage $\mathrm{A} / \mathrm{O}$ reactor. The volume of anoxic zone and aerobic zone could be adjusted by the location of the baffle. In this experiment, the ratio of $\mathrm{A} / \mathrm{O}$ was 1:2. There were mixing devices in anoxic zone for mixing and aerators in aerobic zone for aerating. The hydraulic retention time of multistage $\mathrm{A} / \mathrm{O}$ reactor was designed to be $8 \mathrm{~h}$. The sedimentation zone of vertical flow sedimentation tank was cylindrical and it was $500 \mathrm{~mm}$ in diameter. The sludge hopper was an inverted conical contour with an inclination of $60^{\circ}$. The height of the sludge hopper was $850 \mathrm{~mm}$ and the volume was $90 \mathrm{~L}$. The influent flowed into the reactor through the central pipe and the effluent was drained by the $\mathrm{V}$-weir. The returned sludge was lifted by peristaltic pump.

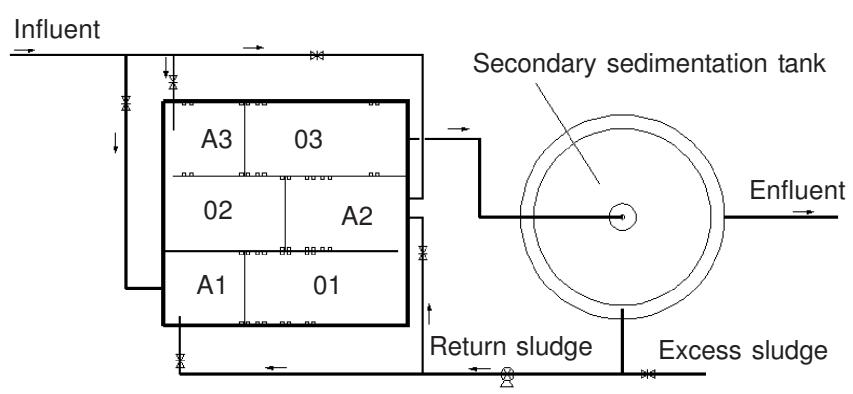

Fig. 1. Schematic diagram of multiple A/O reactor system

Water quality in the experiement: Wastewater in the experiment was come from students' dormitory in Chongqing University B Campus. It was collected by sewer and stored in the tank situated at the outdoors of the laboratory room. Then the wastewater was filtered by the screens to remove the floating projections and large particles of suspended solids and then it was pumped to the high-position tank. At last, the wastewater flowed into the reactor from the high-position tank. The variation range of raw sewage quality was shown in Table-1.

Test items and methods of the water sample: In this experiment, COD is measured with potassium dichromate
TABLE-1

WATER QUALITY OF INFLOW mg/L

\begin{tabular}{ccccc} 
Water quality & $\mathrm{COD}$ & $\mathrm{NH}_{3}-\mathrm{N}$ & $\mathrm{TN}$ & $\mathrm{pH}$ \\
\hline Range & $190-250$ & $30-35$ & $32-40$ & $6.8-8.2$
\end{tabular}

method. Total nitrogen is measured with UV-spectrophotometer; $\mathrm{NH}_{3}-\mathrm{N}$ was measured with nessler's reagents spectrophotometer; $\mathrm{NO}_{3}-\mathrm{N}$ is measured with UV-spectrophotometer; $\mathrm{NO}_{2}-\mathrm{N}$ was measured with $\mathrm{N}$-(1-naphthyl)-ethylenediamine hydrochloride method.

Programs of experiment operating: Considered effectiveness and operability, the multistage $\mathrm{A} / \mathrm{O}$ process was chosen three-stage step-feed mode. The main control parameters were as followed. The volume ratio of anoxic zone and aerobic zone was 1:2. The average sludge concentration descanted by stages, still maintained between 2000-2500 and the VSS/MLSS was 0.75 . The dissolved oxygen concentration $\mathrm{O} 1, \mathrm{O} 2$ and $\mathrm{O} 3$ were $0.4-0.6,0.6-0.8$ and $1.0-1.5 \mathrm{mg} / \mathrm{L}$, respectively by the throttle valve. The exterior reflux ratio was $100 \%$. The experiment was carried out under room temperature. Since the experiment is in process from August 2011 till November 2011, the water temperature was among $20-25^{\circ} \mathrm{C}$ and the HRT was $8 \mathrm{~h}$. There were 3 operating modes of the experiment and they were controlled by the inlet valves in each stage to keep the flow ratios 4:3:3, 5:3:2, 6:3:1 in each case. There was an adaptation period for sludge ages, so when the system was in a stable state, the measurement of the water indicators, sludge characteristic indicators and DO, ORP, $\mathrm{pH}$ of the mixed samples could be carried on.

\section{RESULTS AND DISCUSSION}

Effect of distribution ratios on removal efficiency of COD: In the experiment of discussing the effect of influent flow ratio on removal efficiency of organic matters, the COD treatment efficiency was shown in Fig. 2.

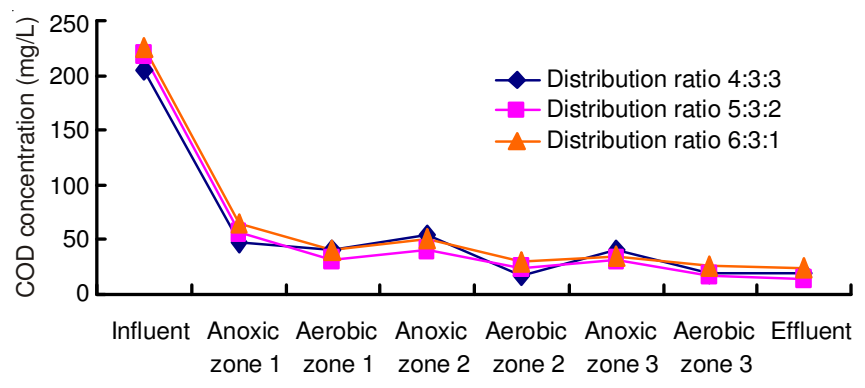

Fig. 2. Variation of COD along the reactor in different flow distribution ratio

Under the $8 \mathrm{~h}$ of hydraulic residence time and different flow ratios, COD of the influent was $200-240 \mathrm{mg} / \mathrm{L}$ and the sludge load was 0.30-0.36 kg COD/(kg MLSS d). However, COD of the effluent was below $30 \mathrm{mg} / \mathrm{L}$ and the removal efficiency was between 85-94\% (the average level was over $90 \%$ ). The effluent COD can meet the standard of "discharge standard of pollutants for municipal waste-water treatment plant" (GB18918-2002) grade1A.It showed that this process had a high removal efficiency and the condition that the influent with low carbon source had little influence on the system's capacity of carbon removal. COD of the effluent was mainly 
composed of non-biodegradable and hard-biodegradable substances. COD concentration of the effluent was at a low level, because the wastewater was the campus sewage and the resource was unitary. In addition, some intermediate product from organic matter decomposed by microorganism and residues from cellular metabolizing were included. It is also believed to be the equilibrium concentration from the degradation of organic compounds when they reach the state of equilibrium $^{12}$.

Effect of influent distribution ratios on removal efficiency of nitrification: As shown in Fig. 3, $\mathrm{NH}_{3}-\mathrm{N}$ concentration of the influent was $30-35 \mathrm{mg} / \mathrm{L}$. It is found by the water quality monitoring along the reactor, that the product from the nitrification stage were almost $\mathrm{NO}_{3}-\mathrm{N}$, accumulative total nitrite nitrogen was very little, $0.5-1.0 \mathrm{mg} / \mathrm{L}$. $\mathrm{NH}_{3}-\mathrm{N}$ of the effluent was $0.2-0.5 \mathrm{mg} / \mathrm{L}$ and the removal efficiency remained over $98 \%$. In conclusion, when $\mathrm{C} / \mathrm{N}$ was 6 , the different flow ratios had little effect on the $\mathrm{NH}_{3}-\mathrm{N}$ removal efficiency. Although under the condition of 6:3:1 flow ration, the nitrification capacity of the aerobic-1-zone was limited, so the $\mathrm{NH}_{3}$ $\mathrm{N}$ concentration was $c a .12 \mathrm{mg} / \mathrm{L}$, the capacity of secondaerobic-zone and third- aerobic-zone were fully content enough to remove $\mathrm{NH}_{3}-\mathrm{N}$. Finally, treatment of $\mathrm{NH}_{3}-\mathrm{N}$ was remained to obtain satisfactory effects (Figs. 3 and 4).

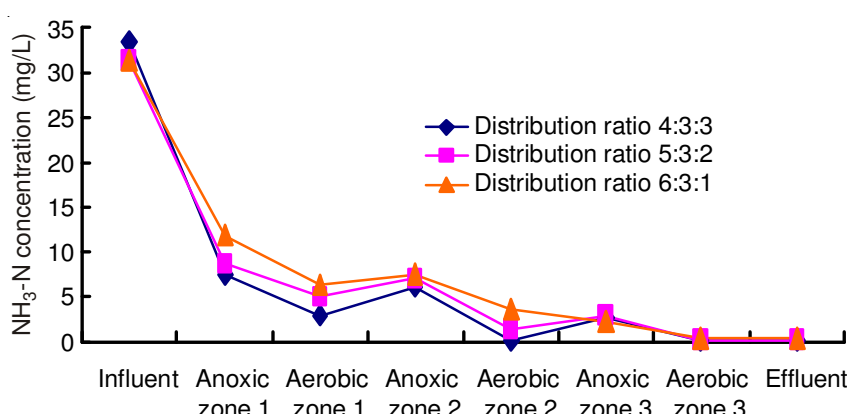

Fig. 3. Variation of $\mathrm{NH}_{3}-\mathrm{N}$ along the reactor in different flow distribution ratio

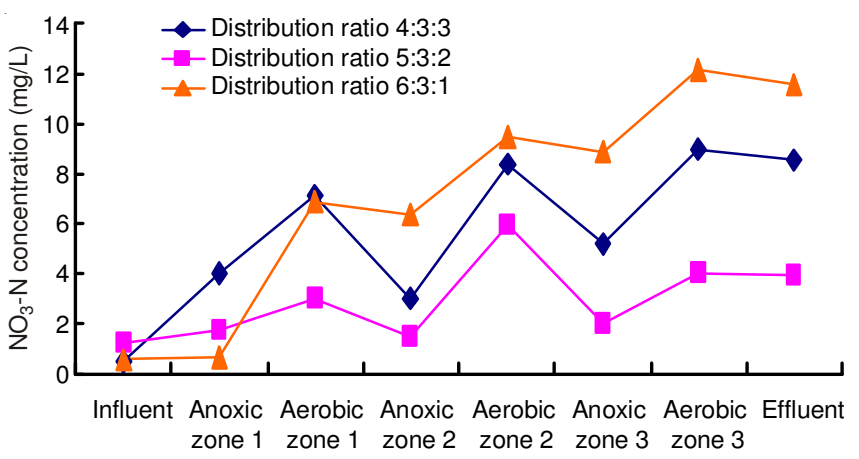

Fig. 4. Variation of $\mathrm{NO}_{3}-\mathrm{N}$ in different flow distribution ratio

The low $\mathrm{NH}_{3}-\mathrm{N}$ concentration in the anoxic zone was the result of dilution effect. In the aerobic zone, because raw wastewater had low carbon source, that is to say that the COD concentration in reactor was low, $\mathrm{NH}_{3}-\mathrm{N}$ was degraded immediately. At the same time, the sludge from the anoxic zone flowed into the aerobic zone. It provided alkalinity for nitrification and improved the effect of nitrification. The degradation time of $\mathrm{NH}_{3}-\mathrm{N}$ was connected with $\mathrm{NH}_{3}-\mathrm{N}$ concentration in the reactor. The higher the $\mathrm{NH}_{3}-\mathrm{N}$ concentration was, the longer the nitrification time. The small experimental trial showed that nitrification rates of the aerobic zone was 0.13 $0.15 \mathrm{~kg} \mathrm{NH} \mathrm{NH}_{3} \mathrm{~N} /(\mathrm{kgMLVSS} \mathrm{d})$ and the $\mathrm{NH}_{3}-\mathrm{N}$ load of the aerobic zone was $0.09-0.11 \mathrm{kgNH}_{3}-\mathrm{N} /(\mathrm{kgMLVSS} \mathrm{d})$. It was figured out the nitrification capacity could meet the nitrification demand.

Effect of distribution ratios on removal efficiency of denitrification: The motoring of $\mathrm{NO}_{2}-\mathrm{N}$ along the way found that there is no accumulation of $\mathrm{NO}_{2}-\mathrm{N}$; it was all below 0.5 $\mathrm{mg} / \mathrm{L}$. So the denitrification effect was shown by removal of $\mathrm{NO}_{3}-\mathrm{N}$. Denitrification bacteria reduced $\mathrm{NO}_{3}-\mathrm{N}$ in the anoxic state to gaseous nitrogen to reach the goal of nitrification. It was shown in Fig. 4 that, when the flow ratio was 4:3:3, the influent of first-stage anoxic zone was too little to provide the carbon source for nitrate in returned sludge for denitrification. This hindered the denitrification proceeding and the accumulation of nitrate reach $4.0 \mathrm{mg} / \mathrm{L}$. In the second-stage anoxic zone, carbon source was relatively high and denitrification reacted fully under this case and surplus nitrates were $3.0 \mathrm{mg} / \mathrm{L}$. In third-stage anoxic zone, the influent flow ratio was $30 \%$, but because of lower sludge concentration and shorter hydraulic retention time. The nitrate concentration of anoxic zone was $5.2 \mathrm{mg} / \mathrm{L}$ and then nitrate nitrogen of the effluent from aerobic zone was $9.0 \mathrm{mg} / \mathrm{L}$.

When the flow ratio was 5:3:2, the nitrification reaction was conducted more completely, so that the denitrification of each stage was more fully reacted. In the last stage with $20 \%$ influent flow ratio, simultaneous nitrification and denitrification was occurred in third- aerobic-zone to some extent, making the nitrate nitrogen concentration around $4.0 \mathrm{mg} / \mathrm{L}$.

When the influent flow ratio was 6:3:1, carbon source was sufficient for denitrification in first-stage, so nitrate concentration of effluent from the anoxic zone was about 0.7 $\mathrm{mg} / \mathrm{L}$. First-anoxic-zone was reacted completely and denitrification degree could reach $90 \%$ at least. But there were less influent in the last two stages, so the carbon source could not meet the demand of $\mathrm{NO}_{3}-\mathrm{N}$ denitrification which was produced by the aerobic zone before. It led to the condition that, $\mathrm{NO}_{3}-\mathrm{N}$ was accumulated stage by stage. Besides, lacking of nitrification volume relatively in first and second aerobic zone made ammonia nitrifying not fully. In the last stage ammonia nitrate converted into $\mathrm{NO}_{3}-\mathrm{N}$, consequently, $\mathrm{NO}_{3}-\mathrm{N}$ in final effluent was at a high level of $12.0 \mathrm{mg} / \mathrm{L}$.

Effect of distribution ratios on removal efficiency of total nitrogen: When carbon source in influent $(\mathrm{C} / \mathrm{N}$ was about 6) maintained the same. The removal efficiency of total nitrogen treated by multistage $\mathrm{A} / \mathrm{O}$ process under different flow ratios was shown in Fig. 5. It is concluded that flow ratio had impact on removal efficiency of total nitrogen. The removal efficiency of nitrate was $70.7 \%$ and total nitrogen of effluent was $10.2 \mathrm{mg} / \mathrm{L}$ in condition that the flow ratio was $4: 3: 3$. The efficiency was $82.9 \%$ and total nitrogen of effluent was 5.7 $\mathrm{mg} / \mathrm{L}$ when the flow ratio was 5:3:2, besides, The efficiency was $59.9 \%$ and total nitrogen of effluent was $13.2 \mathrm{mg} / \mathrm{L}$ when the flow ratio was 6:3:1. In theory, when staged step-feed A/O process was divided into 3 stages and nitrification and denitrification were conducted completely in each stage, the highest 


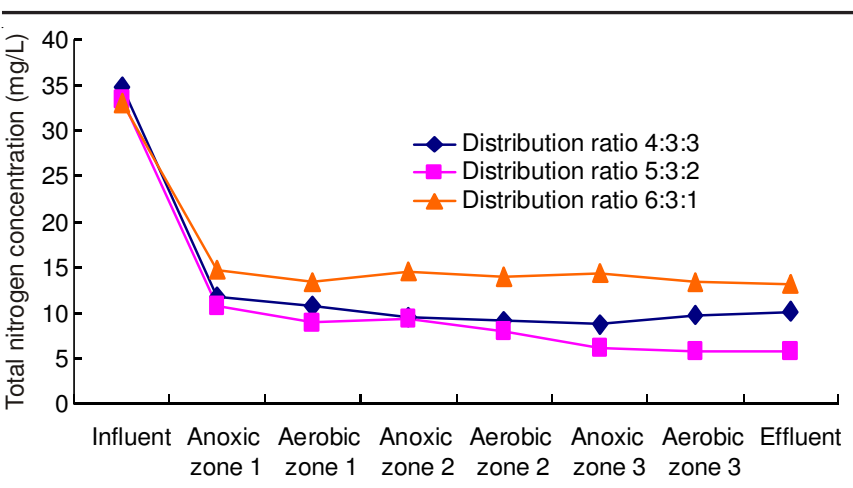

Fig. 5. Variation of total nitrogen in different flow distribution ratio

removal efficient of total nitrogen was $\eta_{\max }=\frac{\alpha+\beta+r}{1+r}$, according to material balance of nitrate nitrogen. In the formula, $\alpha$ represents for the influent flow ratio in first stage. $\beta$ represents for the influent flow ratio in second stage. $r$ represents for the ratio of returned sludge. The theoretically removal efficiency of nitrate was $85 \%$ in condition that the flow ratio was 4:3:3 and it was $90 \%$ when the flow ratio was 5:3:2, besides, it was $95 \%$ when the flow ratio was 6:3:1. There is distinction between the practical efficiency and theoretical efficiency in the research. When improving removal efficiency of the nitrate, complete nitrification and denitrification were required. The capacity of nitrification was almost sufficient in each working condition.

The experiment kept nitrification reacted completely, but denitrification was affected by many factors. For instance, the temperature, the DO in anoxic zone, the volume of denitrification zone, the distribution of flow in each stage and the content of degradable-organic compound in raw wastewater. When flow ratio was 6:3:1, the second and third stage nitrification efficiency was not more than $50 \%$. In the experiment, DO in the first two aerobic zone was controlled at a low level, in order to reduce the DO carried from aerobic zone to the next anoxic zone. This made less consumption of carbon source which was caused by surplus DO. Denitrification was also affected by the content of carbon source. When the $\mathrm{C} / \mathrm{N}$ of the wastewater with low carbon source was 6 , the carbon source was insufficient for denitrification. It has an obvious impact on the removal efficiency of total nitrogen.

As shown in Fig. 5, there was a nitrate losing phenomenon in the aerobic zone. The analysis revealed the occurrence of simultaneous nitrification and denitrification. Research showed that a low DO level was advantageous to occurring simultaneous nitrification and denitrification phenomenon. Simultaneous nitrification and denitrification could improving treatment efficiency remarkably and reduce the tank volume ${ }^{13-15}$. Under the premise that DO was sufficient for nitrification in each stage, aeration could be cut down to achieve simultaneous nitrification and denitrification and short-cut nitrification and denitrification. Thus the demanding of influent $\mathrm{C} / \mathrm{N}$ and aerated energy consumption could be reduced. The material balance of ammonia nitrogen and nitrate nitrogen aspect and fluctuation of alkalinity from decertification aspect to prove that simultaneous nitrification and denitrification phenomenon had happened in step-feed A/O process. And it also quantified the relation between DO concentration and simultaneous nitrification and denitrification phenomenon ${ }^{16-18}$. Therefore, under the premise of ensuring the efficiency of nitrification, intensifying nitrogen removal effect from SND phenomenon was a main point to improve nitrogen removal in multistage $\mathrm{A} / \mathrm{O}$ process.

Therefore, three-stage step-feed A/O system working under condition that $\mathrm{C} / \mathrm{N}$ was 6 and flow distribution ratio was 5:3:2 could achieve the best removal efficiency of nitrogen. The efficiency of total nitrogen removal could reach $82.9 \%$ and it had a close correspondence towards rational and effective usage of carbon source. Totally, step-feed process is superior to single point feed process in the aspect of effective usage of carbon sources in nitration. In the case of low carbon source, effluent from three kinds of influent flow ratios all met grade1A standard.

\section{Conclusion}

In step feed process, under the condition of retained volume ratio of aerobic zone to anoxic, different flow distribution ratios had little impact on removal efficiencies of COD and $\mathrm{NH}_{3}-\mathrm{N}$. They all achieved good removal efficiency. But treatment effects of each zone were different because of the different load distribution.

In step feed process, rational influent flow ratios can make effective use of nitrate source in each stage. And nitrification could make full use of carbon source in raw wastewater, thus the total nitrogen concentration could be controlled at a low level. When the $\mathrm{C} / \mathrm{N}$ maintained 6, effluent from three kinds of influent flow ratios all met grade1A standard. When flow distribution ratio was 5:3:2, the effluent total nitrogen was 5.7 $\mathrm{mg} / \mathrm{L}$ and the removal efficiency was $82.9 \%$, which was better than the denitrification efficiency under the flow distribution ratio of 6:3:1 and 4:3:3. The experiment temperature was 20$25^{\circ} \mathrm{C}$ and it was a suitable temperature for the growth of nitrification bacteria and denitrification bacteria. Therefore, the next stage of research would conduct at a low temperature and offer the best operating mode for the experiment.

\section{ACKNOWLEDGEMENTS}

This work was financially supported by the Fundamental Research Funds for the Central Universities Project (No. 106112012CDJZR210006).

\section{REFERENCES}

1. N. Hvala, M. Zec, M. Ros and S. Strmcnik, Water Environ. Res., 73, 146 (2001).

2. S. Fujii, Water Sci. Technol., 34, 459 (1996).

3. S.C. Qiu and T.T. Ding, China Water Wastewater, 19, 32 (2003).

4. S. Zhang and J.R. Zhu, Environ. Pollut. Control, 29, 533 (2007)

5. R.B. Wang and J. Li, Chin. J. Environ. Eng., 25, 84 (2007).

6. F. Fdz-Polanco, E. Méndez, M.A. Urueña, S. Villaverde and P.A. García, Water Res., 34, 4081 (2000).

7. C. deBarbadillo, L. Carrio, K. Mahoney, J. Anderson, N. Passarelli, F. Streett and K. Abraham, Florida Water Resour. J., 18-20, 33 (2002).

8. G. Olsson, M. Nielsen, Z. Yuan, A. Lynggaard-Jensen and J.-P. Steyer, Instrumentation, Control and Automation in Wastewater Systems, IWA Publishing, London (2005).

9. B.R. Johnson, S. Goodwin, G.T. Daigger and G.V. Crawford, Water Sci. Technol., 52, 587 (2005). 
10. E. Gorgun, E. Artan, D. Orhon and S. Sozen, Water Sci. Technol., 34, 253 (1996).

11. F. Shi, S.J. Liu, B.Y. Ma, X.F. Zheng, X. Yang, Z.X. Zou, J.W. Zhang and K.Z. Sun, Water Wastewater Eng., 37, 34 (2011).

12. M. Henze and P. Harremoes, Chem. Water Wastewater Treatment, 299 (1992).

13. K.A. Third, N. Burnett, C. Cord-Ruwisch, Biotechnol. Bioeng., 83, 706 (2003).

14. K. Pochana and J. Keller, Water Sci. Technol., 39, 61 (1999).
15. W. Sheping, Xi'an Fourth Sewage Plant Influent Water Quality Analysis and sub-A/O Biological Nitrogen Removal Process, School of Civil Engineering, Xi'an University of Architecture and Technology, Xi'an (2006).

16. G.B. Zhu, Y.Z. Peng, S.Y. Wu, S.Y. Wang and S.W. Xu, J. Environ. Sci., 19, 1043 (2007).

17. N. Puznava, M. Payraudeau and D. Thornberg, Water Sci. Technol., 43, 269 (2000)

18. H.X. Littleton, G.T. Daigger, P.F. Strom and R.M. Cowan, Water Sci. Technol., 46, 305 (2002). 